\title{
Emerging treatments for dry age- related macular degeneration with geographic atrophy: a systematic review
}

Ho-Lam Wong ${ }^{1}$; Alvin KH Kwok ${ }^{2}$ MBBS (HK), MD (HK), MD (CUHK), PhD (HK), PDip Epidemiology and Biostatistics (CUHK), FRCSEd, FCSHK, FCOphth HK, FRCOphth, FHKAM (Ophthalmology)

${ }^{\prime}$ Li Ka Shing Faculty of Medicine, University of Hong Kong, Hong Kong SAR

${ }^{2}$ Department of Ophthalmology, Hong Kong Sanatorium Hospital, Hong Kong SAR

Correspondence and reprint requests:

Dr Alvin KH Kwok, 4/F, Li Shu Fan Block, Department of Ophthalmology, Hong Kong Sanatorium Hospital, 2 Village Road, Happy Valley, Hong Kong.Email: alvinkwok@hksh.com

\section{Abstract}

We aim to summarize various emerging treatments for geographic atrophy (GA) secondary to dry age-related macular degeneration (AMD). The PubMed database was searched using keywords: 'treatment' and 'geographic atrophy' or 'dry age-related macular degeneration' on 19 June 2021. Of 121 articles yielded, 20 relevant clinical studies that were of 'English language' and 'published within 10 years' were included. The emerging treatments of dry AMD with GA were categorized into complement inhibitors, diet and supplement, cell-based therapies, and pharmacological agents. Complement inhibitors (C3 inhibitor pegcetacoplan, complement factor D, and C5 inhibitors) can significantly reduce the GA lesion area growth, as can Mediterranean diet and $\alpha$-lipoic acid. Cell-based therapies such as palucorel and biosynthetic retinal pigment epithelium monolayer delivery can minimize GA lesion area and improve the best-corrected visual acuity. Pharmacological agents such as fenretinide, ciliary neurotrophic growth factor, trimetazidine, and brimonidine have prominent effects on GA, but emixustat hydrochloride, tandospirone, and sirolimus lack such effects. The Age-Related Eye Disease Study formulation remains important in reducing the risk of progression of GA secondary to dry AMD. A thorough understanding of the emerging treatment of GA may enable more personalized treatment. Nonetheless, the safety and efficacy of the treatment ought to be tested in trials with larger sample size, longer duration, and optimized dosage.

Key words: Cell- and tissue-based therapy; Complement inactivating agents; Dietary supplements; Geographic atrophy; Macular degeneration

\section{Introduction}

Age-related macular degeneration (AMD) is a chronic progressive disease of the central retina and a major cause of visual impairment. ${ }^{1}$ The prevalence of AMD in the United States population aged $\geq 40$ years is $6.5 \% .^{2}$ By 2040 , AMD is estimated to affect 288 million people in the world. ${ }^{3}$ Approximately $5 \%$ of patients with early AMD progress to a late stage, with an increase of up to $15 \%$ over the past 15 years. ${ }^{4}$ Visual impairment is associated with unemployment, decreased self-support, activity limitation, and lower quality of life. 5

AMD can progress to choroidal neovascularization (wet form) or geographic atrophy (GA) [late dry form], which causes severe vision loss. In dry AMD, retinal pigment epithelium (RPE) undergoes apoptosis, and amorphic 
extracellular deposits (drusens) are formed between RPE and the Bruch membrane, leading to central scotomas and metamorphopsia. In the advanced stage, drusen regresses and hyperpigmentation occurs, resulting in GA. ${ }^{6}$ On optical coherence tomography (OCT), GA is characterized by the atrophy of RPE, photoreceptors, choriocapillaris, and outer nuclear layer. ${ }^{7}$

Unlike neovascular AMD that can be treated with anti-vascular endothelial growth factor, dry AMD with GA secondary to RPE or photoreceptors damage cannot be reversible by current therapies. ${ }^{8}$ Hence, smoking cessation and vitamin or nutritional supplements remain the main option to improve the prognosis of dry AMD. ${ }^{9}$ The Age-Related Eye Disease Study 2 (AREDS2) showed that dietary supplements can lower the risk of the development of wet AMD but have no effects on reducing annual GA lesion area. ${ }^{10}$ This prompts studies to develop novel strategies to minimize GA lesions in patients with dry AMD and to reduce visual morbidity.

We aim to systematically review clinical studies published within 10 years about emerging treatments of GA secondary to dry AMD and their effectiveness in preserving vision. We categorized the treatments into complement inhibitors, diet and supplement, cell-based therapies, and pharmacological agents. The efficacy, safety profile, and limitations of various therapies are discussed and compared.

\section{Methods}

The PubMed database was searched on 19 June 2021 using keywords: 'treatment' and 'geographic atrophy' or 'dry age-related macular degeneration'. Only clinical trials and randomized controlled trials published within 10 years and written in English language were included. Of 121 articles identified, 20 clinical studies describing the novel therapies for dry AMD with GA were included. Review papers, metaanalyses, and case reports were excluded. The 20 studies were manually curated for subject relevance through abstract or full text by one author, followed by discussion on the relevance with another author who made the arbitration when there was disagreement on article selection (Figure).

\section{Results}

The emerging treatments of dry AMD with GA were categorized into complement inhibitors (Table 1), diet and supplement (Table 2), cell-based therapies (Table 3), and pharmacological agents (Table 4).

\section{Complement inhibitors}

Complements are believed to partake in retinal degeneration secondary to AMD. Preclinical studies showed that complement is deposited in the eyes of patients with AMD. ${ }^{11}$ C3 inhibitor pegcetacoplan, complement factor D inhibitor (lampalizumab), and C5 inhibitor were reported to improve the prognosis of dry AMD with GA.

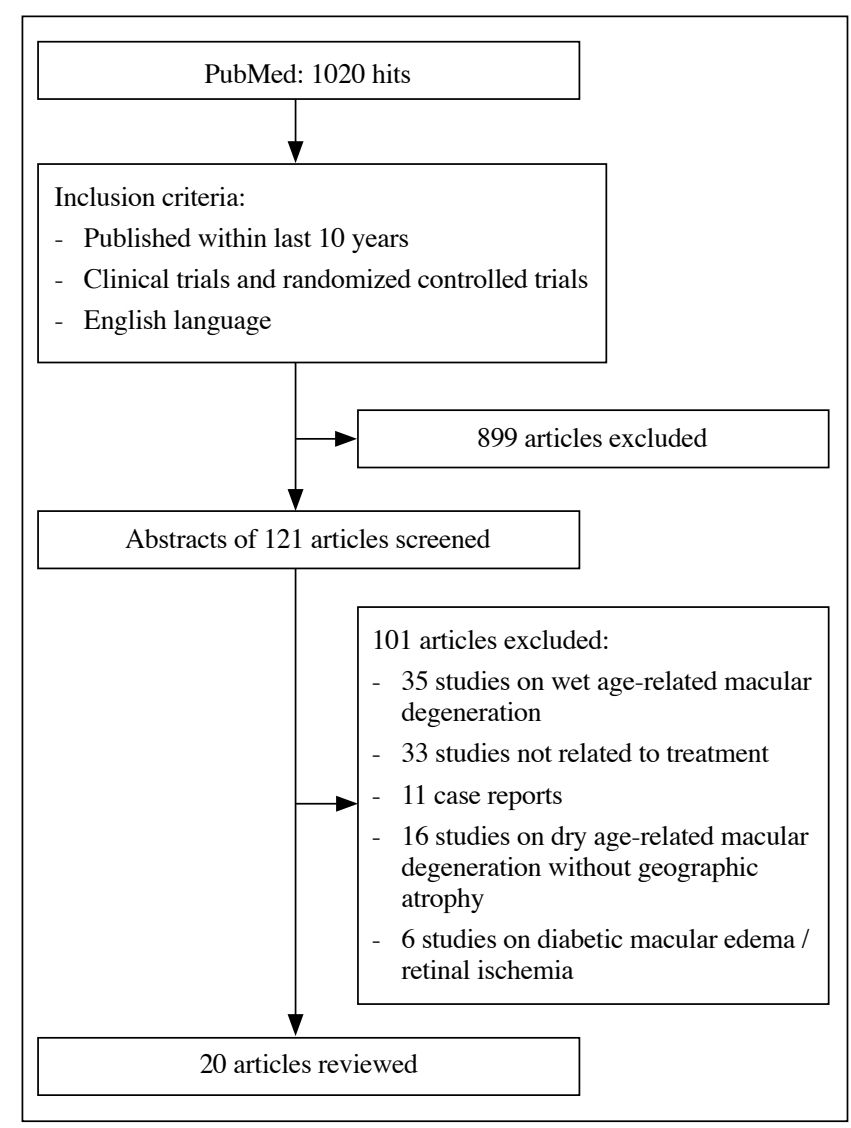

Figure. Flowchart of the PubMed database search strategy.

\section{C3 inhibitor pegcetacoplan}

Complement C3 is the central component of the classical, alternative, and lectin complement activation pathway, which contributes to both innate and adaptive immunity. ${ }^{12}$ Complement activation products have been shown to deposit drusens in dry AMD eyes. ${ }^{13}$ In a phase 2 trial of 246 patients with GA secondary to AMD who were randomized to receive $15 \mathrm{mg}$ pegcetacoplan intravitreal injection monthly, every other month, or sham injection for 12 months and were followed up at months 15 and $18,{ }^{14}$ at month 12 , the increase in square root GA area growth was $29 \%$ smaller in the monthly pegcetacoplan injection group than the sham group $(p=0.008)$, whereas the increase was $20 \%$ smaller in the every other month group than the sham group $(\mathrm{p}=0.067)$. Moreover, untransformed GA lesion reduced $20 \%$ and $30 \%$ in the every other month and monthly groups, respectively, with the effect most significant between months 6 and 12. Upon cessation of pegcetacoplan injection, the GA lesion growth rate showed no decline tendency. This reflects that pegcetacoplan is effective in slowing down the development of GA. However, pegcetacoplan had no prominent effect on the best-corrected visual acuity (BCVA) or foveal encroachment (the distance of GA from the fovea), compared with sham treatment. 
REVIEW ARTICLE

Table 1. Studies of complement inhibitors for dry age-related macular degeneration (AMD) with geographic atrophy (GA)

\begin{tabular}{|c|c|c|c|}
\hline Study & Groups and sample size & Parameters & Main results \\
\hline \multicolumn{4}{|l|}{$\begin{array}{l}\text { C3 Inhibitor } \\
\text { pegcetacoplan }\end{array}$} \\
\hline \multicolumn{4}{|l|}{ Lampalizumab } \\
\hline Holz et al,,$^{17} 2018$ & $\begin{array}{l}906 \text { patients assigned into a ratio of } 2: 1: 2: 1 \text {, } \\
\text { with } 10 \text { mg intravitreal lampalizumab } \\
\text { every } 4 \text { weeks, sham every } 4 \text { weeks, } \\
\text { lampalizumab every } 6 \text { weeks, and sham } \\
\text { every } 6 \text { weeks; assessed for } 96 \text { weeks. }\end{array}$ & $\begin{array}{l}\text { Mean change in GA lesion, } \\
\text { complement factor I-profile genetic } \\
\text { biomarker, best-corrected visual } \\
\text { acuity }\end{array}$ & $\begin{array}{l}\text { Mean GA lesion increased from } 1.93 \text { to } \\
2.09 \mathrm{~mm}^{2} \text { in all groups, with no significant } \\
\text { benefit comparing lampalizumb and sham } \\
\text { for profile biomarker. }\end{array}$ \\
\hline Heier et al, ${ }^{18} 2020$ & $\begin{array}{l}1881 \text { patients randomized into a ratio } \\
\text { of } 2: 1: 2: 1 \text { with } 10 \text { mg intravitreal } \\
\text { lampalizumab every } 4 \text { weeks, sham every } \\
4 \text { weeks, lampalizumab every } 6 \text { weeks, and } \\
\text { sham every } 6 \text { weeks; followed up for } 96 \\
\text { weeks. }\end{array}$ & $\begin{array}{l}\text { Fundus autofluorescence measuring } \\
\text { the GA lesion area, best-corrected } \\
\text { visual acuity, low-luminance visual } \\
\text { acuity, reading speed assessment. }\end{array}$ & $\begin{array}{l}\text { Patients with lampalizumab every } 4 \text { weeks } \\
\text { and } 6 \text { weeks showed } 2.055 \text { and } 2.054 \mathrm{~mm}^{2} \\
\text { enlargement in GA lesion area from baseline, } \\
\text { respectively. }\end{array}$ \\
\hline \multicolumn{4}{|l|}{ Eculizumab } \\
\hline $\begin{array}{l}\text { Yehoshua et al, },^{20} \\
2014\end{array}$ & $\begin{array}{l}30 \text { patients received intravenous eculizumab, } \\
600 \mathrm{mg} \text { weekly for } 4 \text { weeks followed by } \\
900 \mathrm{mg} \text { for } 2 \text { weeks; } 900 \mathrm{mg} \text { weekly for } \\
4 \text { weeks followed by } 1200 \mathrm{mg} \text { for } 2 \text { weeks, } \\
\text { or placebo for } 6 \text { months at a ratio of } 2: 1 \text {. }\end{array}$ & $\begin{array}{l}\text { Square root GA area measurement, } \\
\text { best-corrected visual acuity, low- } \\
\text { luminance visual acuity. }\end{array}$ & $\begin{array}{l}\text { Mean standard GA measurement was } \\
2.55 \mathrm{~mm} \text { and } 2.02 \mathrm{~mm} \text { in the placebo and } \\
\text { eculizumab groups, respectively. GA growth } \\
\text { occurred in both groups at week } 26 \text {. }\end{array}$ \\
\hline \multicolumn{4}{|l|}{$\begin{array}{l}\text { C5 Inhibitor } \\
\text { avacincaptad pegol }\end{array}$} \\
\hline Jaffe et al, 222021 & $\begin{array}{l}286 \text { patients were randomized into a ratio of } \\
1: 2: 2 \text { avacincaptad pegol } 2 \mathrm{mg} \text {, avacincaptad } \\
\text { pegol } 4 \mathrm{mg} \text {, and sham; followed up for } 12 \\
\text { months. }\end{array}$ & $\begin{array}{l}\text { GA area measured by blue light } \\
\text { fundus autofluorescence, best- } \\
\text { corrected visual acuity }\end{array}$ & $\begin{array}{l}\text { Reduction in the mean GA growth rate was } \\
27.4 \% \text { for the avacincaptad pegol } 2 \mathrm{mg} \\
\text { group and } 27.8 \% \text { for the avacincaptad pegol } \\
4 \mathrm{mg} \text { group, compared with corresponding } \\
\text { sham groups. }\end{array}$ \\
\hline
\end{tabular}

Table 2. Studies of diet and supplement for dry age-related macular degeneration (AMD) with geographic atrophy (GA)

\begin{tabular}{|c|c|c|c|}
\hline Study & Groups and sample size & Parameters & Main results \\
\hline \multicolumn{4}{|l|}{ Mediterranean diet } \\
\hline Keenan et al,,$^{25} 2020$ & $\begin{array}{l}4255 \text { participants were assigned to placebo, } \\
\text { antioxidants, zinc, or the combination. } \\
3611 \text { patients received either the above } \\
\text { supplements or with the addition of lutein/ } \\
\text { zeaxanthin, DHA/EPA, or the combination } \\
\text { for } 5 \text { years. }\end{array}$ & $\begin{array}{l}\text { Progression to GA by fundus } \\
\text { photograph grades, alternative } \\
\text { Mediterranean diet index. }\end{array}$ & $\begin{array}{l}\text { Higher adherence to Mediterranean diet, } \\
\text { especially high fish intake, led to lowered } \\
\text { risk of GA or late AMD development, with a } \\
\text { dose dependent association. }\end{array}$ \\
\hline \multicolumn{4}{|l|}{$\alpha$-lipoic acid } \\
\hline Sun et al, ${ }^{29} 2012$ & $\begin{array}{l}32 \text { patients had oral administration of } \\
\alpha \text {-lipoic acid and } 30 \text { patients had oral } \\
\text { placebo for } 3 \text { months; followed up for } \\
3 \text { months. }\end{array}$ & $\begin{array}{l}\text { Serum malondialdehyde, superoxide } \\
\text { dismutase. }\end{array}$ & $\begin{array}{l}\text { Patients with } \alpha \text {-lipoic acid showed lowered } \\
\text { serum malondialdehyde and superoxide } \\
\text { dismutase, compared with placebo group. }\end{array}$ \\
\hline
\end{tabular}




\section{REVIEW ARTICLE}

\begin{tabular}{|c|c|c|c|}
\hline Study & Groups and sample size & Parameters & Main results \\
\hline \multicolumn{4}{|l|}{$\begin{array}{l}\text { Human umbilical } \\
\text { tissue-derived cells } \\
\text { palucorel }\end{array}$} \\
\hline Heier et al, ${ }^{34} 2020$ & $\begin{array}{l}21 \text { patients received single subretinal } \\
\text { administration of palucorecel via } \\
\text { suprachorioidal approach; followed up for } \\
2 \text { years. }\end{array}$ & $\begin{array}{l}\text { Best-corrected visual acuity, GA area, } \\
\text { optical coherence tomography retinal } \\
\text { lesion and central subfield thickness }\end{array}$ & $\begin{array}{l}\text { No improvement in GA area. No significant } \\
\text { change from baseline in square root of area } \\
\text { of GA in intervention eyes compared with } \\
\text { fellow eyes. }\end{array}$ \\
\hline Ho et al, ${ }^{33} 2017$ & $\begin{array}{l}\text { Single dose of palucorecel was placed in the } \\
\text { subretinal fluid bleb adjacent to the GA area } \\
\text { in } 35 \text { patients for } 12 \text { months. }\end{array}$ & $\begin{array}{l}\text { Changes in GA area, best-corrected } \\
\text { visual acuity }\end{array}$ & $\begin{array}{l}>30 \% \text { of participants had a gain of } \geq 10 \text { letters } \\
\text { in best-corrected visual acuity in intervention } \\
\text { eyes. Total GA area increased in intervention } \\
\text { eyes. }\end{array}$ \\
\hline \multicolumn{4}{|l|}{$\begin{array}{l}\text { Biosynthetic retinal } \\
\text { pigment epithelial } \\
\text { monolayer }\end{array}$} \\
\hline Kashani et al ${ }^{36} 2020$ & $\begin{array}{l}20 \text { patients had single subretinal injection } \\
\text { of monolayer of human embryonic stem } \\
\text { cell-derived retinal pigment epithelium; } \\
\text { followed up to } 365 \text { days. }\end{array}$ & $\begin{array}{l}\text { GA area via intraoperative video } \\
\text { analysis }\end{array}$ & $\begin{array}{l}\text { Median GA area at baseline was } 13.8 \mathrm{~mm} \text {, } \\
\text { whereas median GA area left uncovered } \\
\text { by the implant was } 1.7 \mathrm{~mm} .86 .9 \% \text { of } \\
\text { the baseline GA area was covered by the } \\
\text { implant. In } 5 \text { subjects, }>90 \% \text { of the GA area } \\
\text { was covered. }\end{array}$ \\
\hline
\end{tabular}

\section{Lampalizumab}

Complement factor $\mathrm{D}$, a serine protease, is a rate-limiting enzyme of the alternative complement pathway. ${ }^{15}$ Lampalizumab, a monoclonal antibody against complement factor $\mathrm{D}$, is a potential therapeutic target to intervene in the complement activity to reduce the development of GA. In a phase 2 clinical trial of 129 patients with GA secondary to AMD who were allocated to $10 \mathrm{mg}$ intravitreal injection of lampalizumab monthly or every other month or sham injection for 18 months ${ }^{16}$ the least square mean change adjusted for baseline GA area reduced $0.6 \mathrm{~mm}^{2}$ and $-0.2 \mathrm{~mm}^{2}$ in the monthly group and every other month group, respectively, compared with the corresponding sham groups. There was a $20 \%$ reduction in mean change of GA area progression in the monthly group ( $\mathrm{p}=0.117)$. The mean change of $\mathrm{BCVA}$ in the sham group and the monthly group was -4.9 letters and -3.3 letters, respectively. This shows that lampalizumab is an effective and safe treatment for GA.

However, other studies showed no efficacy of lampalizumab in reducing the GA lesion area. In a study of 906 Chroma and 975 Spectri participants with bilateral GA who were assigned to receive intravitreal injection of $10 \mathrm{mg}$ lampalizumab or sham every 4 weeks or every 6 weeks for 96 weeks,${ }^{17}$ at week 48 , the GA lesion area did not significantly differ between the sham groups and the every 4 weeks group $(\mathrm{p}=0.80)$ or the every 6 weeks group $(\mathrm{p}=0.59)$. The mean BCVA letter loss was 5 letters. In addition, complement factor I profile biomarker, a confirmed AMD common risk loci, did not differ significantly across groups. Similarly, in a phase 3 study of 1881 patients who were randomized into intravitreal injection of $10 \mathrm{mg}$ lampalizumab or sham every 4 weeks or every 6 weeks for 96 weeks, ${ }^{18}$ all groups had around a $2 \mathrm{~mm}^{2}$ enlargement in GA lesion area at week 48. There was no significant difference in the BCVA $(\mathrm{p}=0.94)$ or low- luminance visual acuity $(\mathrm{p}=0.49)$ between every 6 weeks group and sham group. Furthermore, binocular or monocular maximum reading speed decreased in all groups, with no significant difference between lampalizumab and sham injection groups.

\section{C5 inhibitor}

Eculizumab, a humanized monoclonal antibody derived from anti-human C5 antibody, is used to treat paroxysmal nocturnal hemoglobinuria and atypical hemolytic uremic syndrome. It inhibits C5 and prevents the formation of membrane attack complex..$^{19}$ In a study of 30 patients with GA who received intravenous injection of eculizumab $600 \mathrm{mg}$ for 4 weeks followed by $900 \mathrm{mg}$ every 2 weeks $(\mathrm{n}=10), 900 \mathrm{mg}$ for 4 weeks followed by $1200 \mathrm{mg}$ every 2 weeks $(\mathrm{n}=10)$, or placebo $(n=10)$ for 24 weeks, ${ }^{20}$ the mean changes of GA did not differ significantly between the eculizumab and placebo groups $(\mathrm{p}=0.96)$, and the change in mean GA enlargement rate did not differ significantly between low-dose and highdose groups $(p=0.40)$. At week 26 , the placebo group showed a higher Early Treatment Diabetic Retinopathy Study visual acuity than the eculizumab groups $(\mathrm{p}=0.019)$ but stopped at week $52(\mathrm{p}=0.43)$.

On the contrary, avacincaptad pegol, a pegylated RNA aptamer that prevents $\mathrm{C} 5$ cleavage, was shown to prevent C5a and C5b formation, thus inhibiting cell death and cell lysis. ${ }^{21}$ In a phase 3 trial of 286 patients with GA who were randomized into intravitreal injection of avacincaptad pegol $2 \mathrm{mg}$ or $4 \mathrm{mg}$ or sham injection for 12 months, ${ }^{22}$ the reduction in mean GA growth rate was $27.4 \%$ in the avacincaptad pegol $2 \mathrm{mg}$ group and $27.8 \%$ in avacincaptad pegol $4 \mathrm{mg}$ group, compared with the corresponding sham groups $(\mathrm{p}=0.0072$ and $\mathrm{p}=0.0051$, respectively). Nonetheless, intravitreal injection of avacincaptad pegol $2 \mathrm{mg}$ or $4 \mathrm{mg}$ did not affect the mean change in BCVA, compared with sham injection. 


\begin{tabular}{|c|c|c|c|}
\hline Study & Groups and sample size & Parameters & Main results \\
\hline \multicolumn{4}{|l|}{$\begin{array}{l}\text { Emixustat } \\
\text { hydrochloride }\end{array}$} \\
\hline $\begin{array}{l}\text { Rosenfeld et al, },^{38} \\
2018\end{array}$ & $\begin{array}{l}508 \text { patients were assigned to } 24 \text { months of } \\
\text { oral daily emixustat } 2.5,5,10 \mathrm{mg} \text { or placebo } \\
\text { at a ratio of } 1: 1: 1: 1 \text {. }\end{array}$ & $\begin{array}{l}\text { Normal luminance best-corrected visual } \\
\text { acuity, total GA area }\end{array}$ & $\begin{array}{l}\text { The annual growth rate for the total area of } \\
\text { GA in the study eyes was similar between } \\
\text { different treatment groups. Mean changes } \\
\text { of normal luminance best-corrected visual } \\
\text { acuity showed no significant difference } \\
\text { across treatment groups. }\end{array}$ \\
\hline \multicolumn{4}{|l|}{ Tandospirone } \\
\hline Jaffe et al, ${ }^{42} 2015$ & $\begin{array}{l}768 \text { patients allocated }(1: 1: 1) \text { to receive } \\
\text { twice-daily AL- } 8309 \mathrm{~B} \text { ophthalmic eyedrop } \\
1.0 \%, 1.75 \% \text {, or vehicle; followed up for } \\
36 \text { months. }\end{array}$ & $\begin{array}{l}\text { Best-corrected visual acuity, total GA } \\
\text { lesion area }\end{array}$ & $\begin{array}{l}\text { An increase in the mean lesion size was } \\
\text { observed in both the AL- } 8309 \mathrm{~B} \text { and vehicle } \\
\text { treatment groups and was similar. Best- } \\
\text { corrected visual acuity did not reveal } \\
\text { significant changes among patients who } \\
\text { received AL- } 8309 \mathrm{~B} \text { compared with those } \\
\text { with vehicle eye drop. }\end{array}$ \\
\hline \multicolumn{4}{|l|}{ Fenretinide } \\
\hline Mata et al, 2013 & $\begin{array}{l}246 \text { patients were allocated }(1: 1: 1) \text { to } \\
\text { receive placebo, } 100 \mathrm{mg} \text { fenretinide and } \\
300 \mathrm{mg} \text { fenretinide for } 2 \text { years. }\end{array}$ & $\begin{array}{l}\text { Visual acuity, GA lesion growth rate, } \\
\text { serum retinol-binding protein level }\end{array}$ & $\begin{array}{l}\text { Patients with } 300 \mathrm{mg} \text { fenretinide resulted in } \\
0.33 \mathrm{~mm}^{2} \text { reduction in annual growth lesion } \\
\text { rate, with retinol-binding protein level } \\
<2 \mathrm{mg} / \mathrm{dL} \text {. }\end{array}$ \\
\hline \multicolumn{4}{|l|}{ Sirolimus } \\
\hline $\begin{array}{l}\text { Petrou et al, }{ }^{49} \\
2014\end{array}$ & $\begin{array}{l}6 \text { participants had one study eye with } 2 \% \\
\text { sirolimus in PEG } 400 \text { and } 4 \% \text { ethanol every } \\
2 \text { months, followed up for } 24 \text { months. }\end{array}$ & $\begin{array}{l}\text { GA area by colour fundus photography } \\
\text { or fundus autofluorescence, best- } \\
\text { corrected visual acuity, central retinal } \\
\text { thickness by spectral-domain optical } \\
\text { coherence tomography }\end{array}$ & $\begin{array}{l}\text { Increase in square root GA area from } \\
\text { baseline was not significant in the study eyes } \\
\text { at months } 6 \text { and } 12 \text { compared with fellow } \\
\text { eyes. }\end{array}$ \\
\hline \multicolumn{4}{|l|}{$\begin{array}{l}\text { Ciliary neurotrophic } \\
\text { factor }\end{array}$} \\
\hline $\begin{array}{l}\text { Zhang et al, },^{52} \\
2011\end{array}$ & $\begin{array}{l}51 \text { patients with GA received NT- } 501 \\
\text { implant injection of high or low dose, or } \\
\text { sham treatment in one eye, for } 12 \text { months. }\end{array}$ & $\begin{array}{l}\text { Best-corrected visual acuity, GA lesion } \\
\text { by fundus photos, retinal thickness by } \\
\text { optical coherence tomography }\end{array}$ & $\begin{array}{l}\text { High- and low-dose ciliary neurotrophic } \\
\text { factor groups had a greater total macular } \\
\text { volume. Progression in GA area was } \\
2.42 \mathrm{~mm}^{2} \text { in sham group, compared with } \\
2.19 \text { and } 2.03 \mathrm{~mm}^{2} \text { in low-dose and high- } \\
\text { dose groups, respectively. }\end{array}$ \\
\hline \multicolumn{4}{|l|}{ Trimetazidine } \\
\hline $\begin{array}{l}\text { Cohen et al, }{ }^{54} \\
2012\end{array}$ & $\begin{array}{l}1086 \text { AMD patients randomized into group } \\
\text { of } 35 \mathrm{mg} \text { trimetazidine tablets twice daily or } \\
\text { placebo for } 3 \text { to } 5 \text { years. }\end{array}$ & $\begin{array}{l}\text { Visual acuity, GA lesion area, and } \\
\text { choroidal neovascularization by retinal } \\
\text { angiography }\end{array}$ & $\begin{array}{l}\text { GA lesion }>1 / 3 \text { disk diameters occurred in } \\
15 \% \text { in trimetazidine group and } 17.5 \% \text { in } \\
\text { the placebo group. The incidence per } 100 \\
\text { patient-years was } 5.11 \text { and } 6.45 \text {, respectively. }\end{array}$ \\
\hline \multicolumn{4}{|l|}{ Brimonidine } \\
\hline $\begin{array}{l}\text { Kuppermann et } \\
\text { al, }{ }^{57} 2021\end{array}$ & $\begin{array}{l}113 \text { patients with GA were grouped into } \\
\text { Brimo DDS } 132 \mu \mathrm{g} \text {, Brimo DDS } 264 \mu \mathrm{g} \text {, } \\
\text { and sham group, with follow up for } 24 \\
\text { months. }\end{array}$ & $\begin{array}{l}\text { Best-corrected visual acuity, mean GA } \\
\text { lesion size, reading speed }\end{array}$ & $\begin{array}{l}\text { The growth in GA lesion area was } \\
\text { significantly reduced by } 19 \% \text { and } 28 \% \text { in } \\
\text { Brimo DDS } 132 \mu \mathrm{g} \text { and } 264 \mu \mathrm{g} \text {, respectively, } \\
\text { compared with the sham group. Brimo DDS } \\
\text { treatment was effective in patients with } \\
\text { baseline GA lesion } \geq 6 \mathrm{~mm}^{2} \text {. }\end{array}$ \\
\hline
\end{tabular}

\section{Diet and supplement}

Mediterranean diet and $\alpha$-lipoic acid were reported to slow down the progression of GA secondary to AMD.

\section{Mediterranean diet}

Mediterranean diet contains a high content of antioxidants and anti-inflammatory nutrients, including vegetables, fruits, nuts, and unsaturated fat.$^{23}$ It has health benefits of lowering the incidence of coronary heart diseases, neurodegenerative diseases, diabetes mellitus, and cancers. ${ }^{24}$ In a retrospective analysis of two cohorts (AREDS and AREDS2), 4255 AREDS participants were allocated to receive placebo, 
antioxidants, zinc or a combination for 5 years, whereas 3611 AREDS2 patients received either AREDS supplements or an addition of lutein/zeaxanthin, docosahexaenoic acid plus eicosapentaenoic acid, or a combination for 5 years. The proportional hazard regression for GA was $0.80(\mathrm{p}=0.0002)$ in AREDS and $0.71(\mathrm{p}<0.0001)$ in AREDS2 for the combined cohort. A higher alternative Mediterranean diet index adherence resulted in a lower risk of GA and late AMD progression. In AREDS, a higher fish intake led to a decreased risk of developing GA and late AMD. Hazard ratios for higher fish intake were $<1$ for GA. These demonstrate that adherence to Mediterranean diet is protective against late AMD and GA progression.

\section{$\alpha$-lipoic acid}

$\alpha$-lipoic acid is an antioxidant that scavenges hydroxyl radicals and nitric oxide. ${ }^{26}$ It protects against oxidative injury and hence reduces the progression of Alzheimer disease, diabetes mellitus, and Parkinson disease. ${ }^{27} \alpha$-lipoic acid also protects RPE cells from oxidation-triggered mitochondrial dysfunction in vitro. ${ }^{28}$ In a clinical trial of 62 patients with dry AMD who were allocated to oral $600 \mathrm{mg} \alpha$-lipoic acid daily or oral placebo daily for 3 months, ${ }^{29}$ no significant difference was found between the two groups in terms of total cholesterol, triglyceride, high-density lipoprotein, and low-density lipoprotein $(\mathrm{p}>0.05)$. However, serum superoxide dismutase increased significantly after $\alpha$-lipoic acid intervention compared with the baseline level $(\mathrm{p}<0.01)$. Superoxide dismutase is an antioxidative enzyme that protects oxidation-induced apoptosis in mouse RPE. ${ }^{30}$ This suggests that $\alpha$-lipoic acid enhances the antioxidant system in slowing down the development of AMD. In addition, serum malondialdehyde slightly decreased in $\alpha$-lipoic acid group; this may be attributed to the increase in serum superoxide dismutase activity.

\section{Cell-based therapies}

Dysfunction and degeneration of the RPE cells are the main pathogenesis of AMD. Cell-based treatments aim to synthesize a RPE layer to deliver cytokines and regenerate the retina. ${ }^{31}$ Palucorel and biosynthetic RPE monolayer has been shown to reduce the worsening of GA in patients with dry AMD.

\section{Human umbilical tissue-derived cells palucorel}

Palucorel consists of human umbilical tissue-derived cells derived from extraembryonic mesoderm. ${ }^{31}$ Unlike mesenchymal stem cells, human umbilical tissue-derived cells do not grow infinitely in culture or differentiate spontaneously in vitro or when transplanted in vivo. ${ }^{32}$ In a phase $1 / 2 \mathrm{~b}$ clinical trial of 35 patients with GA who had palucorel placed in the subretinal space with the creation of a subretinal bleb and were administrated with 27 or $50 \mu \mathrm{L}$ of palucorel and were followed up for 12 months, ${ }^{33}$ the median change in BCVA was 4.5 letters in the intervention eye and -0.5 letters in the fellow eye. $>30 \%$ of participants had a gain of $\geq 10$ letters in BCVA in the intervention eye, but the total GA area increased in the intervention eye. The mean change in the square root of GA area was $0.356 \mathrm{~mm}$ in the intervention eye and $0.336 \mathrm{~mm}$ in the fellow eye. This reflects that palucorel may improve the visual acuity in patients but may not reduce the lesion size of GA.

Similarly, in a phase $2 \mathrm{~b}$ study of 21 patients with GA secondary to AMD who received $50 \mu \mathrm{L}$ of palucorel to the subretinal site using a suprachoroidal approach and were followed up for 2 years, ${ }^{34}$ at month 12 , none achieved the BCVA responder criterion (baseline improvement by $\geq 15$ letters), with a mean change in BCVA of -5.7 in the intervention eye. OCT showed no improvement in retinal lesion thickness or central subfield thickness. The median change of square root of GA area was $0.26 \mathrm{~mm}$ in the intervention and $0.27 \mathrm{~mm}$ in the fellow eyes. Therefore, palucorel shows no significant benefits in terms of BCVA and GA growth rate.

\section{Biosynthetic retinal pigment epithelial monolayer}

Injection of stem cell-derived RPE suspensions did not improve retinal function within the GA area. ${ }^{35}$ Replacement of RPE using a biosynthetic polarized monolayer of RPE was therefore developed. In a phase $1 / 2 \mathrm{a}$ study, an implant named California Project to Cure Blindness Retinal Pigment Epithelium 1 was fabricated, consisting of synthetic parylene substrate and a monolayer of human embryonic stem cellderived RPE. ${ }^{36} 15$ patients underwent macular separation and subretinal pocket formation, followed by insertion of the implant into the subretinal space for 1 year. GA area prominently decreased on post-implantation colour fundus photographs. The median GA area covered by the implant was $86.9 \%$, with 10 patients having $>66 \%$ coverage of the original GA area. The baseline GA size inversely correlated with the percentage of GA area covered by the implant $(p=0.002)$. This reflects that the size of the implant $(3.5 \times 6.25$ $\mathrm{mm}$ ) is appropriate for various GA sizes. The implant inserted through targeted subretinal hydrodissection around the GA area may be a practicable means for patients with GA. This treatment can potentially improve patient vision outcomes, as the procedure does not involve unnecessary detachment of the peripheral retina.

\section{Pharmacological agents}

Emixustat hydrochloride, tandospirone, fenretinide, sirolimus, ciliary neurotrophic factor, trimetazidine, and brimonidine are novel pharmacological treatments that may play a role in reducing GA progression.

\section{Emixustat hydrochloride}

Emixustat is a molecule that hinders the action of a visual cycle isomerohydrolase, RPE65. RPE65 inhibits the mobilization of vitamin A, thus interfering the supply of 11-cis-retinal and reducing bisretinoids accumulation. ${ }^{37}$ Bisretinoids formation led to RPE dysfunction and apoptosis, eventually resulting in GA formation. In a phase $2 \mathrm{~b} / 3$ clinical trial of 968 patients with GA who were randomized to receive oral emixustat $2.5 \mathrm{mg}, 5 \mathrm{mg}$ or $10 \mathrm{mg}$ or placebo for 24 months,${ }^{38}$ the mean change of total GA area was similar across treatment arms $(\mathrm{p} \geq 0.81)$. The adjusted mean of the total GA area was 1.69 , $1.83,1.84,1.69 \mathrm{~mm}^{2} /$ year in the emixustat $2.5 \mathrm{mg}, 5 \mathrm{mg}$, $10 \mathrm{mg}$, and placebo groups, respectively. The annual linear 
growth of total GA area after square root transformation was similar in different groups $(\mathrm{p} \geq 0.94)$. The mean change of normal luminance-BCVA was similar across treatment groups $(\mathrm{p} \geq 0.05)$. The median change in normal luminanceBCVA ranged from -2.0 to -4.0 letters at month 24. Emixustat did not achieve its primary and secondary efficacy end-points including GA lesion growth reduction and normal luminanceBCVA.

\section{Tandospirone}

Tandospirone, a $5 \mathrm{HT}_{1 \mathrm{~A}}$ receptor agonist, is mainly used to treat major depressive disorder and anxiety. ${ }^{39}$ Tandospirone possesses neuroprotective effects after traumatic brain injury and brain ischemia ${ }^{40} \mathrm{~A}$ formulation of tandospirone (AL8309B) was produced for ocular use in the management of GA. An in vivo study revealed that AL-8309B had functional and structural protective effects on RPE and photoceptors under photo-oxidative stress. ${ }^{41}$ In the Geographic Atrophy Treatment Evaluation phase 3 trial, 772 patients with GA were randomized to receive ophthalmic solution AL-8309B 1.0\% or $1.75 \%$ or a vehicle at a ratio of $1: 1: 1$ and were followed up for 36 months, ${ }^{42}$ the mean GA lesion size increased in the AL-8309B and vehicle groups, with no significant difference between groups. The annualized lesion growth rate was $1.73 \mathrm{~mm}^{2}, 1.76 \mathrm{~mm}^{2}$, and $1.71 \mathrm{~mm}^{2}$ in the AL-8309B $1.0 \%$, AL-8309B 1.75\%, and vehicle groups, respectively. Likewise, change in BCVA was comparable among those with AL8309B and those with vehicle eye drops. Only $38 \%$ and $35 \%$ of eyes had BCVA of $\geq 10$ letters after treatment of AL-8309B $1.0 \%$ and AL-8309B $1.75 \%$, respectively. This shows that tandospirone lacks efficacy as an ophthalmic solution.

\section{Fenretinide}

Fenretinide, a synthetic product of vitamin A, is endowed with therapeutic effects on prevention of obesity, type 2 diabetes, and cancer tumours. ${ }^{43}$ Fenretinide competes with retinol and binds to retinol-binding proteins. This helps slow down the formation of a cytotoxic compound, $N$-retinylidene$N$-retinylethanolamine, which was deleterious on RPE. ${ }^{44}$ In a phase 2 trial of 246 patients with GA who received $100 \mathrm{mg}$ or $300 \mathrm{mg}$ daily oral fenretinide or oral placebo for 2 years, ${ }^{45}$ all patients had a loss of 10 to 11 letters in the visual acuity. Nevertheless, the median GA lesion growth rate decreased $0.33 \mathrm{~mm}^{2} /$ year in those with $300 \mathrm{mg}$ fenretinide, compared with placebo group $(\mathrm{p}=0.1848)$. Patients with $100 \mathrm{mg}$ fenretinide revealed a similar trend. This indicates that fenretinide is effective in reducing the growth of GA lesion in a dose-dependent manner. A reduced GA lesion area correlated with a reduced serum retinol binding protein level of $<2 \mathrm{mg} / \mathrm{dL}\left(\mathrm{r}^{2}=0.478\right)$. Hence, reduction in serum retinol binding protein may lead to smaller lesion growth of GA.

\section{Sirolimus}

Sirolimus is an long-term immunosuppressant commonly used after renal transplant. ${ }^{46}$ It inhibits a kinase named mammalian target of rapamycin and leads to a change in cellular metabolism, growth, and survival.$^{47}$ Local sirolimus application have certain effects on ocular pathologies including diabetic macular edema, uveitis, and diabetic retinopathy. ${ }^{48}$
In a phase $1 / 2$ study of six participants with bilateral GA who received intravitreal injection of $2 \%$ of sirolimus for 24 months ${ }^{49}$ the mean absolute increase and square root increase in GA area did not differ significantly between the study eye and the fellow eye on colour fundus photography ( $\mathrm{p}>0.05)$. Four participants resulted in more decrease in central retinal thickness in the study eye, with more retinal thinning in central retinal subfield thickness and macular volume. There was a greater loss of BCVA in the study eye than the fellow eye. These suggest that intravitreal sirolimus may not be safe or effective in managing GA lesions.

In a phase $1 / 2$ study of eight patients with GA who received subconjunctival injection of sirolimus every 3 months for 24 months, ${ }^{50}$ all study and fellow eyes showed an increase in total GA area and showed no significant difference in mean percentage increase and mean absolute increase $(\mathrm{p}=0.41)$. Using colour fundus photography, fundus autofluorescence or confocal scanning ophthalmoscopy, the square root transformation of GA area was similar results between study and fellow eyes. The mean BCVA dropped by 21 letters and 3 letters in the study and fellow eyes, respectively $(\mathrm{p}=0.03)$. The central subfield mean retinal thickness and macular volume decreased progressively in both eyes. This reflects that subconjunctival sirolimus may not be beneficial to minimize GA progression, with an adverse effect on BCVA.

\section{Ciliary neurotrophic factor}

Ciliary neurotrophic factor, a member of the interleukin- 6 family, retards photoreceptor cell death in retinal degeneration. It promotes the survival and differentiation of retinal cells via acting on ciliary neurotrophic factor receptor and downstream signal transduction pathways. ${ }^{51}$ In a phase 2 study of 51 patients with GA who received NT-501 implant injection, followed by high- or low-dose or sham delivery of ciliary neurotrophic factor by encapsulated cell technology in one eye for 12 months, ${ }^{52}$ the total macular volume was greater in high- and low-dose groups than in the sham group $(\mathrm{p}<0.001)$, with the increase more significant in the high-dose group than in the low-dose group $(\mathrm{p}<0.05)$. The low-dose group and the sham group had a greater decline in BCVA, but the high-dose group had relatively stable BCVA. Ciliary neurotrophic factor tended to reduce GA lesion. Progression in GA area was $2.42 \mathrm{~mm}^{2}$ in the sham group, compared with $2.19 \mathrm{~mm}^{2}$ and $2.03 \mathrm{~mm}^{2}$ in the low-dose and high-dose groups, respectively. Hence, ciliary neurotrophic factor may affect GA lesion via its effect on photoreceptors.

\section{Trimetazidine}

Trimetazidine is a fatty acid oxidation inhibitor used in cardiovascular medicine to treat angina, left ventricular dysfunction, and cardiac cell death associated with coronary revascularization procedures. ${ }^{53}$ In a phase 3 trial of 1086 patients with AMD who were randomized to receive $35 \mathrm{mg}$ trimetazidine tablets or placebo twice daily for 3 to 5 years,,$^{54}$ GA lesion $>1 / 3$ disk diameters in central and/or intermediate field occurred in $15 \%$ of patients in the trimetazidine group but $17.5 \%$ of patients in the placebo group. The effect of trimetazidine was more favourable in those of male sex 
$(\mathrm{p}=0.016)$, age $<75$ years $(\mathrm{p}=0.010)$, and presenting with isolated pigmentary changes $(\mathrm{p}=0.005)$. Respectively in the trimetazidine and placebo groups, the incidence per 100 patient-years was 5.11 and $6.45(\mathrm{p}=0.07)$, whereas the estimated 5-year cumulative incidence rate of GA was $30.78 \%$ and $37.94 \%$.

\section{Brimonidine}

Brimonidine is an alpha 2 receptor agonist used to treat glaucoma and ocular hypertension. ${ }^{55}$ It improves the survival of human RPE and Müller cells in vitro and survival of retinal ganglion cells in a rat model after optic nerve injury. ${ }^{56}$ In a phase 2 study that used an intravitreal implant with brimonidine in a biodegradable polymer matrix named Brimo DSS, ${ }^{57} 113$ patients with GA were randomized to receive Brimo DDS $132 \mu \mathrm{g}$ or $264 \mu \mathrm{g}$ or sham treatment and were followed up for 24 months. At month 12, the mean change in GA lesion area in the study eye was $1.78 \mathrm{~mm}^{2}, 1.59 \mathrm{~mm}^{2}$, and $2.19 \mathrm{~mm}^{2}$, respectively. The growth in GA lesion area significantly reduced by $19 \%$ and $28 \%$ after Brimo DDS treatments $(\mathrm{p}=0.032$ and $\mathrm{p}=0.028$, respectively), compared with sham treatment. Brimo DDS treatment was effective in patients with baseline GA lesion $\geq 6 \mathrm{~mm}^{2}$, with a consistent reduction in GA area in both treatment groups at months 3 and 12, compared with the sham group. However, there was no significant improvement or worsening in BCVA or reading speed in study or fellow eye across all groups.

\section{Discussion}

Dry AMD is a common cause of blindness, but there is no approved treatment to reverse the RPE cell loss during the formation of GA. ${ }^{6}$ On the contrary, wet AMD can be effectively managed by intravitreal anti-vascular endothelial growth factor injection. For dry AMD, AREDS formulation remains the only option to reduce the risk of GA progression. ${ }^{10}$ To minimize GA lesion progression, various novel treatments have been proposed and their safety and efficacy assessed. Some are beneficial to BCVA or low-luminance visual acuity and thus have a better visual prognosis in the long run.

For complement inhibitors, C3 inhibitor pegcetacoplan has shown to reduce the mean change in square root GA lesion area, whereas lampalizumab has shown to reduce GA lesion in one study ${ }^{16}$ but not in others. ${ }^{17,18}$ Such discrepancy could be due to selection bias and rigorous exclusion criteria that preclude patients with pre-existing conditions and hence result in a weaker representation of the general population in one study. ${ }^{18}$ In another study, the duration of followup lasted only 48 weeks, and the exclusion and inclusion criteria did not take into account those with unilateral GA and those with GA secondary to causes apart from AMD or earlier disease stages. ${ }^{17}$ The effect of C5 inhibitor on minimizing GA lesion area showed diverse results between studies. One study reported a prominent reduction in GA area after avacincaptad pegol injection; this may be due to the low dose of eculizumab used and the intravenous (rather than intravitreal) route of administration..$^{20} \mathrm{~A}$ systemic route might have hindered the direct delivery of eculizumab to RPE cells. Regarding the safety profile, although pegcetacoplan exerted no significant effect on intraocular pressure, three patients with monthly injection experienced endophthalmitis. ${ }^{14}$ Endophthalmitis occurred in five of 1252 patients with intravitreal lamaplizumb injection. ${ }^{17}$ This suggests the use of a liquid pegcetacoplan formulation without reconstitution to reduce the risk of infection after intravitreal injection.

Cell-based therapy using palucorel showed no significant improvement in GA area. Palucorel was reported to improve BCVA, but the total GA lesion increased after 1 year. ${ }^{33}$ This may be due to the limited sample size of only 35 participants. Interventional bias may also affect the clinical response assessment because the trial was not masked. This may lead to an overestimation of treatment advantages ${ }^{58}$ Likewise, in a study using a suprachoroidal approach, ${ }^{34}$ the small sample size of 21 participants and the lack of masking or randomization may limit the power of the study. In both studies, the fellow eyes were not matched to the intervention eyes for baseline GA lesion and BCVA. ${ }^{34,58}$ Regarding safety of cell-based therapies, $17.1 \%$ of patients experienced retinal detachment and $37.1 \%$ of them had retinal perforations..$^{33}$ Hence, further refinement of the surgical delivery of the umbilical-tissue cells or other cell delivery technologies is required to minimize the risk of complications.

Pharmacological agents including fenretinide, ciliary neurotrophic factor, trimetazidine, and brimonidine were found to reduce GA growth, whereas emixustat hydrochloride, tandospirone, and sirolimus did not result in significant changes in GA lesion. Emixustat failed to treat GA is because emixustat only targets RPE65, the visual cycle enzyme, but not other aspects in the multifactorial pathogenesis of AMD. ${ }^{59}$ Thus, further combination with agents involved in the pathway leading to AMD should be considered. In one study of tandospirone, a rat model with severe acute photo-oxidative stress was used, ${ }^{41}$ and it may not mimic the GA pathogenesis in humans. The dosage and duration of AL-8309B administration may not be optimal and requires further trials. The two studies on sirolimus included only six or eight participants; this decreases the statistical power and increases the margin of error. ${ }^{49,50}$ Initiation rather than progression of GA was postulated to be more related to the immune aetiology of GA and therefore immunosuppressants may not be effective at a later stage. ${ }^{50}$ Emixustat was associated with delayed dark adaption and chromatopsia, ${ }^{38}$ whereas brimonidine Brimo DSS injection led to conjunctival hemorrhage and hyperemia. ${ }^{57}$ Further studies are warranted to confirm the safety of drug therapy.

One limitation to this review study is that only patients with GA were included. Patients with early-stage dry AMD presenting with drusen were excluded. Studies involving potential treatments that prevent progression of dry AMD into choroidal neovascularization were missed out. Nevertheless, we aim to review treatments for GA formation because there is no breakthrough for therapies targeting GA progression. 
The GA lesion contributes to photoreceptor dysfunction and vision loss eventually.

\section{Conclusion}

Complement inhibitors, diet and supplement, cell-based therapies, and pharmacological agents may slow down the progression of GA in terms of mean change of GA lesion area and BCVA. Nonetheless, the safety and efficacy ought to be tested in further trials with larger sample size, longer duration, and optimized dosage. A thorough understanding of the emerging treatment and pathogenesis of dry AMD with GA may enable more personalized management of GA.

\section{Contributors}

All authors designed the study, acquired the data, analyzed the data, drafted the manuscript, and critically revised the manuscript for important intellectual content. All authors had full access to the data, contributed to the study, approved the final version for publication, and take responsibility for its accuracy and integrity.

\section{Conflict of interest}

All authors have disclosed no conflicts of interest.

\section{Funding/support}

This study received no specific grant from any funding agency in the public, commercial, or not-for-profit sectors.

\section{Data availability}

All data generated or analyzed during the present study are available from the corresponding author on reasonable request.

\section{References}

1. Mitchell P, Liew G, Gopinath B, Wong TY.Age-related macular degeneration. Lancet 2018;392:1147-59. Crossref

2. Klein R, Klein BE, Linton KL. Prevalence of age-related maculopathy. The Beaver Dam Eye Study. Ophthalmology 1992;99:933-43. Crossref

3. Wong WL, Su X, Li X, et al. Global prevalence of age-related macular degeneration and disease burden projection for 2020 and 2040: a systematic review and meta-analysis. Lancet Glob Health 2014;2:e106-16. Crossref

4. Mitchell P, Wang JJ, Foran S, Smith W. Five-year incidence of age-related maculopathy lesions: the Blue Mountains Eye Study. Ophthalmology 2002;109:1092-7. Crossref

5. Ejiakor I, Achigbu E, Onyia O, Edema O, Florence UN. Impact of visual impairment and blindness on quality of life of patients in Owerri, Imo State, Nigeria. Middle East Afr J Ophthalmol 2019;26:127-32. Crossref

6. Zajac-Pytrus HM, Pilecka A, Turno-Krecicka A, AdamiecMroczekJ, Misiuk-Hojlo M.The dry form of age-related macular degeneration (AMD): the current concepts of pathogenesis and prospects for treatment. Adv Clin Exp Med 2015;24:1099104. Crossref

7. Arya M, Sabrosa AS, Duker JS, Waheed NK. Choriocapillaris changes in dryage-related macular degeneration and geographic atrophy: a review. Eye Vis (Lond) 2018;5:22. Crossref

8. Bandello F, Sacconi R, Querques L, Corbelli E, Cicinelli $M V$, Querques G. Recent advances in the management of dry age-related macular degeneration: a review. F1000Res 2017;6:245. Crossref

9. Yehoshua Z, Rosenfeld PJ, Albini TA. Current clinical trials in dry AMD and the definition of appropriate clinical outcome measures. Semin Ophthalmol 2011;26:167-80. Crossref

10. Age-Related Eye Disease Study 2 Research Group. Lutein + zeaxanthin and omega-3 fatty acids for age-related macular degeneration: the Age-Related Eye Disease Study 2 (AREDS2) randomized clinical trial. JAMA 2013;309:2005-15. Crossref

11. Klein RJ, Zeiss C, Chew EY, et al. Complement factor $H$ polymorphism in age-related macular degeneration. Science 2005;308:385-9. crossref
12. Vignesh P, Rawat A, Sharma M, Singh S. Complement in autoimmune diseases. Clin Chim Acta 2017;465:123-30. crossref

13. Anderson $D H$, Radeke MJ, Gallo NB, et al. The pivotal role of the complement system in aging and age-related macular degeneration: hypothesis re-visited. Prog Retin Eye Res 2010;29:95-112. Crossref

14. Liao DS, Grossi FV, El Mehdi D, et al. Complement C3 inhibitor pegcetacoplan for geographic atrophy secondary to age-related macular degeneration: a randomized phase 2 trial. Ophthalmology 2020;127:186-95. Crossref

15. Volanakis JE, Narayana SV.Complement factor D, a novel serine protease. Protein Sci 1996;5:553-64. Crossref

16. Yaspan BL, Williams DF, Holz FG, et al. Targeting factor D of the alternative complement pathway reduces geographic atrophy progression secondary to age-related macular degeneration.Sci Transl Med 2017;9:eaaf1443. Crossref

17. Holz FG, Sadda SR, Busbee B, et al. Efficacy and safety of lampalizumab for geographic atrophy due to age-related macular degeneration: Chroma and Spectri phase 3 randomized clinical trials. JAMA Ophthalmol 2018;136:666-77. Crossref

18. Heier JS, Pieramici D, Chakravarthy $U$, et al. Visual function decline resulting from geographic atrophy: results from the Chroma and Spectri phase 3 trials. Ophthalmol Retina 2020;4:673-88. crossref

19. Maga TK, Nishimura CJ, Weaver AE, Frees KL, Smith RJ. Mutations in alternative pathway complement proteins in American patients with atypical hemolytic uremic syndrome. Hum Mutat 2010;31:E1445-60. Crossref

20. Yehoshua Z, de Amorim Garcia Filho CA, Nunes RP, et al. Systemic complement inhibition with eculizumab for geographic atrophy in age-related macular degeneration: the COMPLETE study. Ophthalmology 2014;121:693-701. Crossref

21. Li W, Chen S, Ma M, Qian J, MaX. Complement 5b-9 complexinduced alterations in human RPE cell physiology. Med Sci Monit 2010;16:BR17-23.

22. Jaffe GJ, Westby K, Csaky KG, et al.C5 Inhibitor avacincaptad pegol for geographic atrophy due to age-related macular degeneration: a randomized pivotal phase $2 / 3$ trial. Ophthalmology 2021;128:576-86. Crossref

23. Widmer RJ, Flammer AJ, Lerman LO, Lerman A. The 
Mediterranean diet, its components, and cardiovascular disease. Am J Med 2015;128:229-38. Crossref

24. Dinu M, Pagliai G, Casini A, Sofi F. Mediterranean diet and multiple health outcomes: an umbrella review of meta-analyses of observational studies and randomised trials. Eur J Clin Nutr 2018;72:30-43. crossret

25. Keenan TD, Agron E, Mares J, et al. Adherence to the Mediterranean diet and progression to late age-related macular degeneration in the Age-Related Eye Disease Studies 1 and 2. Ophthalmology 2020;127:1515-28. Crossref

26. Packer L, Roy S, Sen CK. Alpha-lipoic acid: a metabolic antioxidant and potential redox modulator of transcription. Adv Pharmacol 1997;38:79-101. Crossref

27. Liu J, Ames BN. Reducing mitochondrial decay with mitochondrial nutrients to delay and treat cognitive dysfunction, Alzheimer's disease, and Parkinson's disease. Nutr Neurosci 2005;8:67-89. crossref

28. Jia L, Liu Z, Sun L, et al. Acrolein, a toxicant in cigarette smoke, causes oxidative damage and mitochondrial dysfunction in RPE cells: protection by (R)-alpha-lipoic acid. Invest Ophthalmol Vis Sci 2007;48:339-48. Crossref

29. Sun YD, Dong YD, Fan R, Zhai LL, Bai YL, Jia LH. Effect of (R)-alpha-lipoic acid supplementation on serum lipids and antioxidative ability in patients with age-related macular degeneration. Ann Nutr Metab 2012;60:293-7. Crossref

30. Kasahara E, Lin LR, Ho YS, Reddy VN. SOD2 protects against oxidation-induced apoptosis in mouse retinal pigment epithelium: implications for age-related macular degeneration. Invest Ophthalmol Vis Sci 2005;46:3426-34. Crossref

31. Cao J, Murat C, An W, et al. Human umbilical tissue-derived cells rescue retinal pigment epithelium dysfunction in retinal degeneration. Stem Cells 2016;34:367-79. crossref

32. Lund RD, Wang $S, L u B$, et al.Cells isolated from umbilical cord tissue rescue photoreceptors and visual functions in a rodent model of retinal disease. Stem Cells 2007;25:602-11. Crossref

33. Ho AC, Chang TS, Samuel M, Williamson P, Willenbucher RF, Malone T. Experience with a subretinal cell-based therapy in patients with geographic atrophy secondary to age-related macular degeneration. Am JOphthalmol 2017;179:67-80. crossref

34. Heier JS, Ho AC, Samuel MA, et al. Safety and efficacy of subretinally administered palucorcel for geographic atrophy of age-related macular degeneration: phase $2 b$ study. Ophthalmol Retina 2020;4:384-93. Crossref

35. Schwartz SD, Tan G, Hosseini H, Nagiel A. Subretinal transplantation of embryonic stem cell-derived retinal pigment epithelium for the treatment of macular degeneration: an assessment at 4 years. Invest Ophthalmol Vis Sci 2016;57:ORSFC1-9. Crossref

36. Kashani AH, Uang J, Mert M, et al. Surgical method for implantation of a biosynthetic retinal pigment epithelium monolayer for geographic atrophy: experience from a phase 1/2a study. Ophthalmol Retina 2020;4:264-73. crossref

37. Petrukhin K. Pharmacological inhibition of lipofuscin accumulation in the retina as a therapeutic strategy for dry AMD treatment. Drug Discov Today Ther Strateg 2013;10:e11-e20. Crossref

38. Rosenfeld PJ, Dugel PU, Holz FG, et al.Emixustat hydrochloride for geographic atrophy secondary to age-related macular degeneration: a randomized clinical trial. Ophthalmology 2018;125:1556-67. Crossref

39. Lin J, Su Y, Wang C, et al. Effects of tandospirone augmentation in major depressive disorder patients with high anxiety: a multicenter, randomized, parallel-controlled, open-label study. J Psychiatr Res 2018;99:104-10. Crossre

40. Bode-Greuel KM, Klisch J, Horvath E, Glaser T, Traber J.Effects of 5-hydroxytryptamine1A-receptor agonists on hippocampal damage after transient forebrain ischemia in the Mongolian gerbil. Stroke 1990;21(12 Suppl):IV164-6.

41. Collier RJ, Patel Y, Martin EA, et al. Agonists at the serotonin receptor (5-HT1A) protect the retina from severe photo-oxidative stress. Invest Ophthalmol Vis Sci 2011;52:2118-26. Crossref

42. Jaffe GJ, Schmitz-Valckenberg S, Boyer D, et al. Randomized trial to evaluate tandospirone in geographic atrophy secondary to age-related macular degeneration: the GATE Study. Am J Ophthalmol 2015;160:1226-34. Crossref

43. Mody N, Mcllroy GD. The mechanisms of Fenretinide-mediated anti-cancer activity and prevention of obesity and type-2 diabetes. Biochem Pharmacol 2014;91:277-86. Crossref

44. Sparrow JR, Zhou J, Ben-Shabat S, Vollmer H, Itagaki Y, Nakanishi K. Involvement of oxidative mechanisms in blue-lightinduced damage to A2E-laden RPE. Invest Ophthalmol Vis Sci 2002;43:1222-7.

45. Mata NL, Lichter JB, Vogel R, Han Y, Bui TV, Singerman LJ. Investigation of oral fenretinide for treatment of geographic atrophy in age-related macular degeneration. Retina 2013;33:498-507. Crossref

46. Camardo J. The Rapamune era of immunosuppression 2003: the journey from the laboratory to clinical transplantation. Transplant Proc 2003;35(3 Suppl):18S-24S. Crossref

47. Kahan BD. Sirolimus: a comprehensive review. Expert Opin Pharmacother 2001;2:1903-17. Crossref

48. Agarwal A, Rajagopalan N, Hassan M, et al. Sirolimus for retinal and uveitic diseases. Dev Ophthalmol 2016;55:276-81 . Crossref

49. Petrou PA, Cunningham D, Shimel K, et al.Intravitreal sirolimus for the treatment of geographic atrophy: results of a phase I/II clinical trial. Invest Ophthalmol Vis Sci 2014;56:330-8. Crossref

50. Wong WT, Dresner S, Forooghian F, et al. Treatment of geographic atrophy with subconjunctival sirolimus: results of a phase I/II clinical trial. Invest Ophthalmol Vis Sci 2013;54:294150. crossref

51. Fuhrmann S, Kirsch M, Hofmann HD. Ciliary neurotrophic factor promotes chick photoreceptor development in vitro. Development 1995;121:2695-706. Crossref

52. Zhang K, Hopkins JJ, Heier JS, et al.Ciliary neurotrophic factor delivered by encapsulated cell intraocular implants for treatment of geographic atrophy in age-related macular degeneration. Proc Natl Acad Sci U S A 2011;108:6241-5. Crossref

53. Marzilli M, Vinereanu D, Lopaschuk G, et al. Trimetazidine in cardiovascular medicine. Int J Cardiol 2019;293:39-44. Crossref

54. Cohen SY, Bourgeois H, Corbe C, et al. Randomized clinical trial France DMLA2: effect of trimetazidine on exudative and nonexudative age-related macular degeneration. Retina 2012;32:834-43. Crossref

55. Lusthaus JA, Goldberg I. Brimonidine and brinzolamide for treating glaucoma and ocular hypertension; a safety evaluation. Expert Opin Drug Saf 2017;16:1071-8. Crossref

56. Ramírez C, Cáceres-del-Carpio J, Chu J, et al. Brimonidine can prevent in vitro hydroquinone damage on retinal pigment epithelium cells and retinal müller cells. JOcul Pharmacol Ther 2016;32:102-8. Crossref

57. Kuppermann BD, Patel SS, Boyer DS, et al. Phase 2 study of the safety and efficacy of brimonidine drug delivery system (Brimo DDS) generation 1 in patients with geographic atrophy secondary to age-related macular degeneration. Retina 2021;41:144-55. Crossref

58. Schulz KF, Chalmers I, Hayes RJ, Altman DG. Empirical evidence of bias. Dimensions of methodological quality associated with estimates of treatment effects in controlled trials. JAMA 1995;273:408-12. Crossref

59. Zhang J,Kiser PD,Badiee M, et al.Molecular pharmacodynamics of emixustat in protection against retinal degeneration. J Clin Invest 2015;125:2781-94. Crossref 